\title{
Флотская префектура и ее место в системе римского командования (ранняя Римская империя)
}

\author{
Телепень С.В. \\ Мозырский государственный педагогический университет им. И.П. Шамякина, \\ Белоруссия, 247760, г. Мозырь, Гомельская обл., ул. Студенческая, 28 \\ Email: telepen_serg@mail.ru
}

\begin{abstract}
Аннотация. Предметом статьи является флотская префектура Римской империи I-II вв. Роль и место префектов флота в системе военного командования рассматриваются в связи с анализом формировавшейся в данный период схемы всаднической военной и административной карьеры. На основании литературных и эпиграфических источников показаны предпосылки и этапы эквитской карьеры. В статье обосновывается точка зрения о возраставшей заинтересованности императоров в использовании назначенцев из числа всадников - в качестве альтернативы командирам и администраторам из среды сенаторов. Подчеркивается, что интерес со стороны всадников к участию в государственных делах также возрастал, что нашло выражение в стремлении эквитов запечатлеть этапы своей карьеры в соответствующих надписях. Соответственно, в статье рассматривается проблема постепенного встраивания флотской префектуры в систему эквитских постов. Показано, что итогом стало превращение данной префектуры (во всяком случае, что касается командования крупнейшими флотами Империи) в должность прокураторского уровня. Последнее находит объяснение в важной роли, которую римские флотские соединения играли в обеспечении римского господства как в центральной части государства, так и на далекой его периферии.
\end{abstract}

Ключевые слова: флот Римской империи, императорская власть, римское всадничество, эквитская карьера, префектура, провинции, прокураторы.

Для цитирования: Телепень С.В. 2021. Флотская префектура и ее место в системе римского командования (ранняя Римская империя). Via in tempore. История Политология. 48 (4): 755-765. DOI: $10.52575 / 2687-0967-2021-48-4-755-765$.

\section{Naval prefecture and its place in the roman command system (early Roman Empire)}

\author{
Sergey V. Telepen' \\ Mozyr State Pedagogical University named after I.P. Shamyakin, \\ 28 Studencheskaya St., Mozyr, Gomel' region, 247760, Byelorussia \\ Email: telepen_serg@mail.ru
}

\begin{abstract}
The subject of the article is the naval prefecture of the Roman Empire in the 1st - 2nd centuries. The role and place of the prefects of the fleet in the system of military command is considered in connection with the analysis of the scheme of the equestrian military and administrative career that was formed in this period. Based on literary and epigraphic sources, the prerequisites and stages of the Equit career are shown. The article substantiates the point of view of the growing interest of the emperors in the use of appointees from among the equites as an alternative to commanders and administrators from among the senators. It is emphasized that the interest on the part of equites to participate in state affairs also increased which found expression in the desire of equites to capture the stages of their career in the inscriptions. Respectively, the article deals with the problem of the gradual integration of the naval prefecture into the system of Equit posts. It is shown that the result was the transformation of this prefecture (at least with regard to the command of the largest fleets of the Empire) into a position of the
\end{abstract}


procuratorial level. This is explained in the important role that the Roman naval formations played in ensuring Roman rule both in the central part of the state and on its distant periphery.

Keywords: navy of the Roman Empire, imperial power, Roman equestrian order, equestrian career, prefecture, provinces, procurators.

For citation: Telepen S.V. 2021. Naval prefecture and its place in the roman command system (early Roman Empire). Via in tempore. History and political science. 48 (4): 755-765 (in Russian). DOI: 10.52575/2687-0967-2021-48-4-755-765.

\section{Введение}

Римская флотская префектура - явление, изученное далеко не полностью. Своей эволюцией она отражает процесс становления и развития не только римских военноморских сил, но и административного аппарата империи. В условиях «республиканской монархии» бюрократизация государственного аппарата управления была лишь вопросом времени [Межерицкий, 2016, с. 783]. Императорские вольноотпущенники, столь значимые в качестве доверенных лиц и назначенцев Юлиев-Клавдиев, должны были постепенно уступить место всадникам как более авторитетным представителям принцепса, к тому же способным составить реальную политическую конкуренцию сенаторам, оставаясь при этом зависимыми от воли императора. Положение командира одной из двух италийских флотилий - Мизенской или Равеннской - могло бы в этом случае сделать фигуру доверенного эквита, сменившего в данном качестве императорского вольноотпущенника, сопоставимой с всаднической же фигурой префекта претория.

\section{Результаты и их обсуждение}

Необходимо отметить, что занятие флотской префектуры не было основным способом продвижения по всаднической карьерной лестнице. Вообще начальный этап этой лестницы был связан с прохождением военной службы на офицерских должностях уровня от командира когорты до префекта алы [Ле Боэк, 2001, с. 57-58]. В этой связи принято говорить о militiae equestres, т. е. о военном этапе эквитской карьеры, состоявшей обычно из трех таких должностей (tres militiae), последовательно занимавшихся всадником в течение нескольких лет. Для этого, как и для занятия сенаторских командирских постов, достаточно было принадлежности к данному сословию, в то время как предварительный армейский опыт не требовался [Davenport, 2019, p. 255]. Зато этап militiae equestres считался необходимым для последующего назначения эквита на административные должности прокураторского уровня [Талберт, 2018, с. 390].

Если верить Светонию (Suet. Claud. 25. 1), данная система в общих чертах определилась при императоре Клавдии (41-54). Далее император Вителлий за время своего недолгого правления (всего несколько месяцев 69 г.) продолжил заменять на важных административных должностях императорских вольноотпущенников всадниками (Tac. Hist. I. 58. 1). Это не могло не способствовать усилению позиций всадников также и в качестве командиров. Соответственно, при императоре Адриане (117-138), как предполагает, опираясь на данные эпиграфики, Сеголен Демужэн, в рамках militiae equestres был добавлен четвертый пост - префекта двойной (т. е. состоявшей из 1000 кавалеристов) алы, а система всаднической карьеры (ее военного этапа) приобрела завершенный вид [Demougin, 1988, p. 353-355]. Что касается продолжительности militiae equestres, то в науке высказываются различные мнения. Ряд историков, исследующих римскую императорскую армию в целом, полагают, что на каждой из трех-четырех должностей, занимавшихся эквитом в течение военного этапа его карьеры, он проводил в среднем три года [Webster 1998, p. 113; Ле Боэк, 2001, с. 57; Hassal, 2007, 335; Southern, 2007, p. 129]. Эти данные, очевидно, восходят к предположению Эрика Бирли, сделанному им еще в середине XX в. [Birley, 
1953, p. 137]. Однако Питер Брант, специально изучавший вопрос о всаднической службе, убедительно опроверг аргументы Бирли, доказав, что служба на каждой такой командирской должности продолжалась обычно лишь год [Brunt, 1983, p. 47]. Нет оснований сомневаться в том, что флотская префектура эквитов в основном должна была характеризоваться схожими условиями ее прохождения.

Между тем впервые две постоянные флотилии для защиты Италии были созданы еще Августом. Они были дислоцированы в Равенне и Мизене [Reddé, 1986, p. 472]. Впрочем, в период правления Августа и затем Тиберия командование над обоими флотами - Равеннским и Мизенским - не стало еще интегральной частью эквитского cursus honorum. Лоуренс Кеппи пишет: «При Августе триерархов и навархов часто набирали в приморских городах-государствах [греческого] Востока. В то время префекты флота обычно назначались из числа военных трибунов или старших центурионов» [Кеппи, 2018, р. 437]. К тому же в науке существует обоснованное мнение о том, что флот Римской империи не играл существенной роли в ее военной организации, что было связано с превращением Средиземного моря после битвы при Акции в римское mare nostrum [Банников, Морозов, 2014, с. 34-35].

Явно неполноправное в сравнении с армией положение флота, по мнению многих исследователей, означало и относительно невысокий вначале статус флотских префектов. Кеппи дает здесь следующее объяснение: «Командование флотом больше не требовало специальных мореходных знаний или особых склонностей к военным действиям на море; единственным требованием теперь оставались лишь административные навыки» [Keppie, 1984, p. 186]. В другом месте этот исследователь высказывается по поводу префектов Мизенского и Равеннского флотов: «им не требовалось воинского опыта, поскольку их обязанности были в основном административными, и порой одним из префектов флота становился вольноотпущенник императора, пользовавшийся особым доверием последнего» [Кеппи, 2018, p. 448]. Неудивительно, что флотскими командирами на заре Империи могли быть, помимо вольноотпущенников, представители такой не слишком уважаемой в римской армейской среде категории, как греки [Bowie, 2014, p. 41-42, 61]. Показательно также, что в условиях кризиса 68-70 гг. человеческие ресурсы италийских флотов были использованы, чтобы сформировать два новых легиона - I и II Вспомогательные (Тас. Hist. II. 43, 67; Dio LV. 24. 2).

Что касается такого критерия значимости флота (а значит, и его префектов), как численность в сравнении с сухопутными силами, то Ян Ле Боэк предполагает, что во всей Римской империи на флоте служило около 40 тыс. человек, т. е чуть более $10 \%$ всех вооруженных сил государства, составлявших около 300 тыс. [Ле Боэк, 2001, с. 48]. «Общую численность обоих [италийских] флотов можно оценить лишь ориентировочно, примерно в 15-20 тыс. чел., которые составляли экипажи приблизительно семидесяти пяти - ста кораблей» [Кеппи, 2018, р. 437]. Провинциальные флоты были явно меньше. Например, флоты в Сирии и Египте насчитывали, вероятно, по 2,5 тыс. чел. [Kissel, 1995, S. 37]. Paзумеется, как-то влиять на политическую ситуацию в этих условиях могли лишь командиры Мизенского и Равеннского флотов.

Чем была флотская префектура, мы можем судить, как правило, исходя из данных эпиграфики. Эквиты в эпоху Империи быстро усвоили традицию военачальников и администраторов сенаторского ранга отображать этапы своей карьеры в торжественных надписях [Bruun, 2015, p. 285; Davenport, 2019, p. 256-260], что дало возможность исследователям реконструировать некую общую схему всаднической карьеры. Первым, кто осуществил эту работу, был Ханс-Георг Пфлаум, чьи труды по данному вопросу не потеряли свой актуальности и поныне. Пфлаум связывал возникновение всаднических рангов уровня прокуратуры с градуированием вознаграждения за занятие эквитской должности. Так, в четвертой главе второй части своего просопографического труда «Прокураторы в Ранней Римской империи» (1950) [Pflaum, 1950, p. 210-296] Пфлаум пишет о прокураторских рангах, определявшихся суммой официального вознаграждения прокуратора. Согласно 
мнению автора, не только между рангами, но и внутри них существовала некая иерархия. Пфлаум заключает, что прохождение этих карьерных ступеней было «великим правилом римской иерархии» (la grand règle de la hiérarchie romain) [Pflaum, 1950, p. 295]. Соответственно, префекты римского императорского флота могут быть разделены на три группы, различающиеся уровнем вознаграждения:

- вознаграждавшиеся суммой в 60 тыс. сестерциев в год - префекты Сирийского, Мезийского, Паннонского и Сирийского флотов;

- 100 тыс. - Британского, Германского и Понтийского;

- 200 тыс. - Равеннского и Мизенского.

T. е. префекты Мизенского и Равеннского флотов получали вознаграждение, аналогичное тому, которое полагалось командирам легионов, имевшим сенаторский ранг [Коnen, 2001, S. 303]. Следовательно, обе италийские флотские префектуры причислялись к высшим командным постам. Пфлаум относит должность префекта Равеннского флота к третьей по престижности среди всех всаднических, занятие которых вознаграждалось двумястами тысячами сестерциев, а пост префекта Мизенского, соответственно, ставит еще выше [Pflaum, 1950, p. 254]. Соответственно, флотские префектуры, вознаграждавшиеся ста тысячами сестерциев, должны считаться более высокими в сравнении с прокураторскими постами, за которые полагалась аналогичная сумма. Конкретно, по мнению Пфлаума, три префектуры, которые предполагали оперирование в открытом море (префектуры флотов Британского, Германского и Понтийского), относились к такому высшему «эшелону» [Pflaum, 1950, p. 235].

Можно сказать, что «Клавдий интегрировал обе италийские флотские префектуры в прокураторскую иерархию» [Pflaum, 1950, p. 47]. Возможно также, что первые провинциальные флотилии были организованы также при нем. Обоим же италийским флотам было присвоено, вероятно, при Веспасиане [Pflaum, 1950, p. 47] или Домициане [Keppie, 1984, p. 187] почетное определение praetoria. По мнению Ги Вагнера, Мизенский флот «получил звание преторианского в 71 г. и потерял его после переноса столицы из Рима в Константинополь в 330 г.» [Wagner, 1995, p. 129]. Но возможно также, что италийские флотилии просто принадлежали к главной императорской ставке - praetorium [Alföldy, 1987, p. 47]. Т. е. это может означать, что италийские флотилии, поскольку они базировались близ Рима, находились под верховным командованием самого императора [Forny, 1986, p. 210].

Интересно мнение, согласно которому «Мизенский флот был в основном вовлечен в гражданские дела, в то время как Равеннский в основном был сосредоточен на военных функциях» [Kunić, 1996, p. 95]. Как полагает Алка Кунич, личный состав Равеннского флота составлял 5 тыс. чел. (33 корабля этого флота зафиксированы источниками), а Мизенский флот был в два раза больше - 10 тыс. чел. и 76 кораблей [Kunić, 1996, p. 97]. Paзумеется, Мизенский флот выглядит здесь более значимым, что подтверждает мнение Пфлаума о преимущественном значении должности командира Мизенского флота (см. выше). С другой стороны, «не известно, был ли размер Мизенского флота больше, чем Равеннского» [Eck, Lieb, 1993, S. 88].

Однако для полноты картины представляется необходимым оценить также роль префектов провинциальных флотов. Наиболее естественным здесь представляется рассмотреть положение и функции тех военно-морских сил, которые таким командирам эквитского статуса были поручены. Например, Британский флот был римлянами создан между 40 и 43 гг. I в. н. э. в процессе подготовки императора Клавдия к вторжению на Британские острова [Holder, 1982, p. 132]. Главной базой этого флота была Бонония (совр. Булонь). В 1-й пол. II в. стоянка этого флота переместилась в порт Дубры (Portus Dubris, или Dubrae совр. Дувр). К сожалению, «о британском флоте известно не очень много. Так, не известны типы и количество кораблей, как и количество моряков (возможно, не менее 500). Наиболее вероятно, что основным типом кораблей здесь был либурн» [Holder, 1982, p. 40]. 
Удивительно, но некоторые префекты британского флота, очевидно, могли иметь ранг центуриона (CIL VI. 1643). Главной функцией этого флота была скорее всего невоенная. Как полагает, опираясь на данные эпиграфики, Пол Холдер, «это была по преимуществу транспортировка железа на континент» [Holder, 1982, p. 132]. Как бы там ни было, «к концу III в. Британский флот, вероятно, перестал существовать, будучи разделен на небольшие эскадры, которые разместились при фортах Саксонского берега» [Holder, 1982, p. 133]. Мы можем предположить, что данное рассредоточение было связано с разделением самой Британии на новые провинции.

Германский флот использовался главным образом для переброски войск с одного берега Рейна на другой. «При Августе и в начале правления Тиберия флоты играли важную роль в римской экспансии вглубь Германии... Они использовались как транспортное средство и для проведения разведывательных операций» [Saddington, 1990, p. 225]. Возможно, в самом начале на Рейне были созданы временные флотилии и лишь затем - постоянный Германский флот. Его главная база расположилась тремя километрами южнее Колонии Агриппины (совр. Кельн) [Maxfield, 1990, p. 146]. Однако надо учитывать при этом, что римский флот оперировал в этом регионе еще до учреждения германских провинций. Тиберий (Velleus II. 106. 2-3) и Германик (Тac. Ann. I. 45. 3, 60. 3, II. 6. 2) использовали флот для транспортировки своих войск. Друз Старший «первым из римских военачальников совершил плавание по северному Океану и прорыл за Рейном каналы для кораблей» (Suet. Claud. 2) (пер. М.Л. Гаспарова). «Как наместник Нижней Германии Корбулон преследовал пиратов вдоль галльского побережья в 47 г. н. э., выведя в море корабли из устья Рейна (Tac. Ann. XI. 18. 2)» [Isaac 1990, 102]. Позже система каналов сделала возможным переброску войск из Средиземного моря на Северное море от начала до конца пути на судах (Tac. Ann. XIII. 53). «Можно предположить, что постоянный флот на Рейне был создан при Клавдии» [Saddington 1990, p. 220].

К сожалению, известны только несколько командиров Германского флота (CIL III. 782; CIL VI. 1643). «Те командиры, которые нам известны, являются исключительно выходцами из Средиземноморского региона и особенно Италии» [Konen, 2001, S. 331]. Как замечает Генрих Конен, командиры Германского и Британского флотов получали эти свои назначения только после tres militia [Konen, 2001, S. 331]. Это, в свою очередь, указывает на важное значение, которое играли данные флотские префекты в системе обороны указанных провинций.

Появление постоянного римского флота на Дунае, возможно, относится ко времени создания провинции Мёзии, во время правления Августа. Тем не менее присутствие римских военных кораблей на Дунае зафиксировано еще до учреждения этой провинции (около 15 г. н. э.). «Первым, кто сообщает о присутствии римского флота на Дунае, является Овидий, что было связано с событиями 12 г. н. э.» [Bounegru, Zahariade, 1996, p. 1]. Мёзийский флот был организован, вероятно, при Клавдии: «Флот на Дунае впервые упоминается в 50 г., когда вождь свевов был вынужден бежать к римлянам» [Saddington, 1991, p. 398]. Тацит пишет буквально: «И все же ему (вождю свевов Ваннию - C.T.) пришлось бежать к поджидавшему его на Дунае нашему флоту» (Тас. Ann. XII. 30) (пер. А.С. Бобовича). Трудно сказать, когда этот флот получил почетное звание «Флавианского». Возможно, это произошло при Веспасиане [Старр, 2015, с. 194] либо при Домициане [Berard, 1989, p. 133]. Мёзийский Флавианский флот - такое название присутствует на дипломе 92 (CIL XVI. 37). Карл Штробель замечает, что оба дунайских флота (Мёзийский и Паннонский) получили наименование «Флавианский» за ту роль, которую они и их префекты сыграли на Дунае в период Дакийских войн Домициана в 90-е гг. I в. [Strobel, 1989, S. 16]. Но возможно, что Мёзийский флот получил наименование «Флавианский» уже в 86 г. [Strobel, 1989, S. 70]. «При Флавиях по крайней мере один командир Мёзийского флота отвечал за "Дунайский берег”» [Wilkes, 1983, p. 267]. Этот префект - Марк Аррунций Клавдиан [PIR ${ }^{2}$ II, p. 162, nо. 753] - позже даже был возведен в сенаторский ранг, запечатлев этапы своей военной карье- 
ры, что вообще было характерно для сенаторов, выслужившихся из командиров всаднического статуса [Maurizi, 2013, p. 22-28; Bruun, 2015, p. 274-275].

Несомненно, главной базой Мёзийского флота был Новиодун (совр. Исакча в Румынии). Мёзийский флот оперировал как на Дунае, так и на Черном море. «Мёзийский Флавианский флот делился на две части - морскую и речную» [Bounegru, Zahariade, 1996, p. 32]. «Мёзийский Флавианский флот патрулировал западный и южный берега Черного моря. Подразделения флота базировались в Херсонесе и в Боспорском клиентском царстве» [Żyromski, 2001, p. 15]. К сожалению, о деятельности Мёзийского флота и его командиров в период Дакийских войн Траяна мы знаем лишь из изображений колонны Траяна. Некоторые сцены показывают здесь флот транспортирующим войска и снаряжение, отражающим диверсионные атаки даков, эскортирующим военачальников, включая самого Траяна [Rossi, 1971, p. 132, 148, 149, 174]. Конечно, единственный мост через Дунай, построенный Аполлодором из Дамаска, не мог выполнить все логистические задачи, стоявшие перед римским командованием в этой зоне. Важная роль деятельности Мёзийского флота в ходе обеих Дакийских войн Траяна может быть удостоверена на основании того факта, что некоторые из высших офицеров консулярного ранга получили флотскую награду - corona classica (ILS 1022). Надпись 147 г. отражает еще одну необычную функцию Мёзийского флота - транспортировка диких животных для игр, устраивавшихся императором ( $A E$ 1987, 867). По мнению Тадеуша Сарновского, два хорошо известных (из письма наместника Мёзии I в. н. э. Флавия Сабина) эпарха - Азиатик и Аррунций Фламма - были командирами Мёзийского флота [Sarnowski, 1987, p. 263-264]. Вероятно, кем-то из этих префектов для состава этого провинциального флота была организована система медицинской помощи, о которой сообщает надпись: N. Seius Ga[---]ius medicus duplicar(ius) / [clas]sis Fl(aviae) Moes(icae) ( $A E$ 1995, 1350).

Август, вероятно, создал флот на Дунае с целью обороны Паннонии. Однако затем зона действия этого флота расширилась, охватив также Мёзию. Паннонский флот имел свою постоянную базу в Тавруне (совр. Земун, p-н Белграда) на р. Саве, недалеко от Сингидуна (также в настоящ. вр. терр. Белграда) [Wilkes, 1983, p. 267]. По мнению Карла Штробеля, Паннонский флот получил наименование Флавианского за свое участие в Паннонской войне Домициана, которую тот вел в 89 г. [Strobel, 1989, S. 83 n. 2]. Далее, обнаруженная в Керепесе (недалеко от Будапешта) надпись, посвященная Паннонскому Флавианскому флоту, позволила предположить существование флота в так и не созданных провинциях Сарматии и Маркоманнии [Soproni, 1990, S. 732].

Во время правления Нерона был создан Понтийский флот. Его ядро состояло из кораблей, входивших во флот Понтийского царства, чья территория была римлянами захвачена в 62 или 64 г. н. э. В 66 г. этот флот состоял из 40 кораблей (Joseph. B.J. II. 366/7). Главным местом стоянки Понтийского флота, реорганизованного при Домициане, был Трапезунд или Синопа [French, 1984, p. 59]. Командир Понтийского флота руководил выполнением важных логистических функций [Kissel, 1995, S. 39].

Также, вероятно, существовал флот на Красном море (in Mari Rubro), однако о нем нам мало что известно, кроме того, что его создал Траян (Eutrop. VIII 3. 2). Причем это могло быть как море, до сих пор называемое Красным, так и Персидский залив. Если подразумевалось все-таки второе, то при Адриане этот флот должен был прекратить свое существование [Isaac, 1990, p. 127]. Тем не менее ни один командир этого флота из источников не известен. Сирийский флот, созданный, вероятно, Веспасианом, был скорее береговой стражей, чем настоящим флотом, а его главной стоянкой стала Селевкия Пиерия, располагавшаяся недалеко от Антиохии, главного города провинции (в 6 км к северу от устья p. Оронт) [Żyromski, 2001, p. 17]. Между тем «подразделения этого флота стояли в Мавретании по крайней мере со времен Адриана и почти до конца правления Марка Аврелия» [Adams, 1985, p. 141].

В 197 г., готовясь к войне с Парфией, Септимий Север создал речную флотилию на Евфрате (Dio LXXV. 9) или Тигре (Herod. III. 9). В этом отношении Север, очевидно, по- 
вторил аналогичный опыт Траяна, также организовывавшего речные силы в связи с подобной же парфянской кампанией [Adams, 1985, p. 158-161]. Тем не менее «в отличие от других речных границ - по Рейну и Дунаю - реки Месопотамии не показывают присутствия здесь постоянного флота, как и Сирийский флот не выглядит задействованным здесь» [Adams, 1985, p. 163]. Наиболее вероятно, что Египетский флот был также вовлечен в выполнение полицейских и таможенных функций на Ниле.

«Что касается Фракии, ... то здесь нет свидетельств о том, что когда-либо существовал Фракийский флот» [Adams, 1985, p. 124]. Classis Perinthia, название которой, вероятно, происходит от Перинфа, главного города этой провинции, была, скорее всего, лишь почетной флотилией фракийского наместника, а не настоящим флотом [Żyromski, 2001, p. 17].

Таким образом, римский имперский флот образовывал в своей совокупности систему, которая охватывала не только Средиземное море, но практически всю Римскую империю. Хотя морские и речные военные силы были подчинены сухопутной армии, они часто играли очень важную роль, особенно во время больших военных кампаний, как, например, Дакийские войны Траяна. Из вышесказанного следует, что роль флота Римской империи могла быть достаточно существенной в том, что касается обеспечения стабильности не только на морских, но и на речных путях, причем как в центральной части государства, так и на далекой его периферии. В этой связи роль флотской префектуры уже не выглядит столь незначительной, какой она была, вероятно, при Августе.

Можно предположить, что старшие офицеры флота (префекты и субпрефекты) не были настоящими флотоводцами, тем более в свете вышесказанного о преимущественно административном характере части флотских префектур. Но. с другой стороны, старшие римские офицеры, по сути, генералы, которые командовали легионами (т. е. легаты легионов) также не были профессиональными военными в современном смысле слова [Devijver, 1998, p. 205-206; Махлаюк, 2002, с. 24-25]. Впрочем, в науке высказывается мнение и о том, что командиры не только сенаторского, но и всаднического статуса могли быть в достаточной мере подготовлены к командованию воинами [Rankov, 2008, p. 39]. При этом противопоставление всадников сенаторам здесь довольно условно. Всадники занимали свои посты, оставаясь тесно связанными, в том числе семейными узами, с сенаторами, которые на личных связях обеспечивали представителей всадничества командирскими должностями [Birley, 2003, p. 8-9; Rees, 2007, p. 160-162; Davenport, 2019. p. 264]. Поэтому трудно согласиться с Брианом Кэмпбеллом, который пишет, что «это было прерогативой сенаторов командовать римскими легионами. Эквиты были назначаемы в качестве префектов флота не потому, что моряки представляли угрозу императору, а ввиду непрестижности для сенаторов занимать подобный пост» [Campbell, 1988, p. 239]. В конце концов, с самого начала принципата даже легионы не все возглавлялись командирами сенаторского ранга, примером чего является императорский Египет (Suet. Tib. 52. 2; Dio. LI. 17. 1).

\section{Выводы}

Постепенно роль эквитов как более лояльного и вместе с тем авторитетного слоя в римской администрации и армии возрастала - вплоть до реформ Галлиена, который вообще освободил сенаторов от участия в командовании вооруженными силами (Aur. Vict. Caes. XXXIII. 34). Отсюда следует, что назначение на командирские посты членов всаднического сословия может рассматриваться как выражение эволюционных изменений в римском государстве, развивавшемся в направлении бюрократизации государственной машины, где флотская префектура занимала достаточно важное место. Значимость этого положения обуславливалась не только преторианским статусом Мизенского и Равеннского флотов, но и, очевидно, возраставшей ролью флотов провинциальных. 


\section{Список литературы}

1. Банников А.В., Морозов М.А. 2014. История военного флота Рима и Византии (от Юлия Цезаря до завоевания крестоносцами Константинополя). СПб., Евразия, 592.

2. Кеппи Л. 2018. Армия и военный флот. Пер. с англ. В кн.: Боумэн А.-К., Чэмплина Э., Линтотта Э. (ред.). Кембриджская древняя история. Т. 10: Империя Августа 43 г. до н. э. - 69 г. н. э. М., Ладомир: 424-453.

3. Ле Боэк Я. 2001. Римская армия эпохи Ранней Империи. Пер. с франц. М., РОССПЭН, 400.

4. Махлаюк А.В. 2003. Scientia rei militaris (к вопросу о «профессионализме» высших военачальников римской армии). Вестник Нижегородского университета им. Н.И. Лобачевского. Серия История. Вып. 1: 13-31.

5. Межерицкий Я.Ю. 2016. «Восстановленная республика» императора Августа. М., Русский фонд содействия образованию и науке, 992.

6. Старр Ч. 2015. Флот Римской империи. Роль военно-морских сил в поддержании обороноспособности и сохранении античного государства со времен Октавиана Августа и до Константина Великого. Пер. с англ. М., Центрполиграф, 287.

7. Талберт Р. Дж. А. 2018. Сенат и посты, которые занимали в государстве сенаторы и всадники. Пер. с англ. В кн.: А.-К. Боумэн, Э. Чэмплина, Э. Линтотта (ред.). Кембриджская древняя история. Т. 10: Империя Августа 43 г. до н. э. - 69 г. н. э. М., Ладомир: 373-393.

8. Adams J.P. 1985. Logistics of the Roman imperial army. Major campaigns on the eastern front in the first three centuries A. D. Ann Arbor, University Microfilms International, 298.

9. Alföldy G. 1987. Römische Heeresgeschichte. Amsterdam, Verlag J.C. Gieben, 575.

10. Berard F. 1989. La cohorte I a Cilicum, la classis Flavia Moesica et les vexillations de l'armée de Mésie inférieure: À propos d'une inscription de Montana. Zeitschrift für Papyrologie und Epigraphik, Bd. 79: 129-138.

11. Birley E. 1953. The equestrian officers in the Roman army. In: Birley E. Roman Britain and the Roman Army. Kendal, Titus Wilson \& son LTD, 1953: 133-153.

12. Bounegru O., Zahariade M. 1996. Les forces navales du Danube et de la Mer Noire aux Ier VIe siècles. Oxford, Oxbow Books, 1996, XII, 124.

13. Bowie E. 2014. Becoming wolf, staying sheep. In: Madsen J.M., Rees R. (eds.). Roman Rule in Greek and Latin Writing: Double Vision. Leiden, Brill, 39-78.

14. Brunt P.A. 1983. Princeps and Equites. The Journal of Roman Studies, vol. 73: 42-75.

15. Bruun C. 2015. Roman Government and Administration. In: Bruun C., Edmondson J. (eds.), The Oxford Handbook of Roman Epigraphy. Oxford, Oxford University Press: 274-298.

16. Campbell B. 1988. Rewiew: Reddé M. Mare Nostrum: Les Infrastructures, le Dispositif et l'Histoire de la Marine Militaire sous l'Empire Romain. The Journal of Roman Studies, vol. 78: 239.

17. Davenport C. 2019. A History of the Roman Equestrian Order. Cambridge, Cambridge University Press, xxv, 717. Rome, 923.

18. Demougin S. 1988. L'ordre équestre sous les Julio-Claudiens. Rome, École Francaise de

19. Devijver H. 1998. Commanders and officers of legio IIII Scythica. In.: Kennedy D.L. (ed.), The twin towns of Zeugma on the Euphrates: rescue work and historical studies. Portsmouth, RI: 205-232.

20. Eck W., Lieb H. 1993. Ein Diplom für die classis Ravennas vom 22. November 206. Zeitschrift für Papyrologie und Epigraphik, Bd. 96: 75-88.

21. Forni G. 1986. I diploma military dei classiari delle flotte pretorie (inclusi quelli dei classiari-legionari). In: Eck W., Wolff H. (Hrsg.), Heer und Integrationspolitik die römischen Militärdiplome als historische Quelle. Köln., Böhlau: 193-321.

22. French D.H. 1984. Classis Pontica. Epigraphica Anatolica, Bd. 4: 53-60.

23. Hassal M. 2007. The Army. In: The Cambridge Ancient History. Vol. 11. The High Empire, A. D. 70-192. Cambridge, Cambridge University Press: 320-343.

24. Holder P.A. 1982.The Roman Army in Britain. New York, St. Martin's Press, 173.

25. Isaac B. 1990. The limits of empire. The Roman Army in the East. Oxford, Clarendon Press, $\mathrm{XIV}, 510$.

26. Keppie L. 1984. The making of the Roman army from Republic to Empire. London, B.T. Batsford Ltd, XI, 255. 
27. Kissel Th. 1995. Untersuchungen zur Logistik des römischen Heeres in den Provinzen des griechischen Ostens (27 v. Chr. - 235 n. Chr.). St. Katharinen, Scripta-Mercaturae Verl, XI, 405.

28. Konen H.C. 2001. Classis Germanica die römische Rheinflotte im 1-3 Jahrhundert n. Chr. St. Katharinen, Scripta Mercaturae Verlag, 578.

29. Kunić A.D. 1996. Classis Praetoria Ravennatium with special reflection on sailors that on sailors that origin from Dalmatia and Pannonia. Živa antika, sv. 46: 95-110.

30. Maurizi L. 2013. Il cursus honorum senatorio da Augusto a Traiano: sviluppi formali e stilistic nell'epigrafia latina e greca. Helsinki, Societas Scientiarum Fennica, XII, 324.

31. Maxfield V.A. 1990. Mainland Eurupe. In: Wacher J. (ed.), The Roman World. Vol. 1: 139-197.

32. Pflaum H.-G. 1950. Les procurateurs équestres sous le Haut-empire Romain. Paris, Adrien Maisonneuve, 357.

33. PIR ${ }^{2}$ - Groag E., Stein A. (iter. et edid.) 1936. Prosopographia Imperii Romani. Saec. I. II. III. Pars II. Sec. ed. Berolini et Lipsiae, XXII, 399.

34. Rankov B. 2008. Military forces. In.: Sabin P., van Vees H., Whitby M. (eds.) The Cambridge History of Greek and Roman Warfare. Vol. II: Rome from the Late Republic to the Late Empire. Cambridge, Cambridge University Press: 30-75.

35. Reddé M. 1986. Mare Nostrum: les infrastructures, le dispositif et l'histoire de la marine militaire sous l'empire romain (Bibliothéque des Écoles françaises d'Athènes et de Rome CCLX). Rome, École Française de Rome, ix, 737.

36. Rossi L. 1971. Trajan's column and the Dacian Wars. Ithaca, N.Y., Cornell University Press, 240.

37. Saddington D. 1990. The origin and nature of the German and British Fleets. Britannia, vol. 21: $223-232$.

38. Saddington D. 1991. The origin and Character of the provincial fleets of the Early Roman Empire. In: Maxfield V.A., Dobson M.J. (eds.), Roman frontier studies 1989. Proceedings of the XVth International Congress of Roman Frontier Studies. Exeter, University of Exeter Press: 397-399.

39. Sarnowski T. 1987. Zur Geschichte der Moesischen Provinzialflotte im 1 Jr. n. Chr. Ratiariensia, № 3/4: 261-265.

40. Soproni S. 1990. Vexillationes Classis Flaviae Pannonicae. In.: Vetters H., Kandler M. (Hrsg.), Akten des 14 Internationalen Limeskongresses 1986 in Carnuntum, Wien, Verlag der Osterreichischen Akademie der Wissenschaften: 731-736.

41. Southern P. 2007. The Roman Army. A Social and Instutional History. Oxford, Oxford University Press, XI, 383 p.

42. Strobel K. 1989. Die Donaukriege Domitians. Bonn, Habelt, 151.

43. Wagner G. 1995. Deux inscriptions grecques d'Égypte. Zeitschrift für Papyrologie und Epigraphik, Bd. 106: 126-130.

44. Webster G. 1998. The Roman Imperial Army of the of the First and Second Centuries A. D. (3d Edition). Norman, University of Oklahoma Press, XXIII, 349.

45. Wilkes J.J. 1983. Romans, Dacians and Sarmatians in the first and early second centuries. In.: Hartley B., Wacher J. (eds.), Rome and her Northern Provinces. Papers Presented to Sheppard Frere in Honour of his Retirement from the Chair of the Archaeology of the Roman Empire, University of Oxford. Gloucester, Alan Sutton: 255-289.

46. Żyromski M. 2001. Praefectus classis. The commanders of the Roman imperial navy during the Principate. Poznań, Wyd. Instytutu Nauk Politycznych i Dziennikarstwa Uniwersytetu im. A. Mickiewicza w Poznaniu, 2001, 157.

\section{References}

1. Bannikov A.V., Morozov M.A. 2014. Istorija voennogo flota Rima i Vizantii (ot Julija Cezarja do zavoevanija krestonoscami Konstantinopolja) [The history of the navy of Rome and Byzantium (from Julius Caesar to the conquest of Constantinople by the crusaders)]. Saint Petersburg, Evrazija, 592 (in Russian).

2. Keppie L. 2018. Armija i voennyj flot [The army and the navy]. In: Bowman A.-K., Champlin E., Lintott A. (eds.). Kembridzhskaja drevnjaja istorija. T. 10: Imperija Avgusta 43 g. do n. je. -69 g. n. je. [The Cambridge Ancient History. Vol. X: The Augustan Empire, 43 B. C. - A. D. 69]. Moscow, Ladomir: 424-453 (in Russian). 
3. Le Bohec Y. 2001. Rimskaja armija jepohi Rannej Imperii [The imperial Roman army]. M., ROSSPEN, 400 (in Russian).

4. Mahlajuk A.V. 2003. Scientia rei militaris ( $\mathrm{k}$ voprosu o «professionalizme» vysshih voenachal'nikov rimskoj armii) [Scientia rei militaris (on the "professionalism" of higher commanders of the Roman army)]. Vestnik Nizhegorodskogo universiteta im. N.I. Lobachevskogo. Serija Istorija [Vestnik of Lobachevsky State University of Nizhny Novgorod. Social Sciences]. Issue. 1: 13-31 (in Russian).

5. Mezheritskiy Ya.Yu. 2016. «Vosstanovlennaya respublika» imperatora Avgusta [Emperor Augustus' «Restored Republic»]. Moscow, Russian foundation for science and education, 992 (in Russian).

6. Starr Ch. 2015. Flot Rimskoj imperii. Rol' voenno-morskih sil v podderzhanii oboronosposobnosti i sohranenii antichnogo gosudarstva so vremen Oktaviana avgusta i do Konstantina Velikogo [The Roman Imperial Navy 31 B. C. - A. D. 324]. Moscow, Centrpoligraf, 287 (in Russian).

7. Talbert R. J. A. 2018. Senat i posty, kotorye zanimali v gosudarstve senatory i vsadniki [The Senate and senatorial and equestrian posts]. In: Bowman A.-K., Champlin E., Lintott A. (eds.). Kembridzhskaja drevnjaja istorija. T. 10: Imperija Avgusta 43 g. do n. je. -69 g. n. je. [The Cambridge Ancient History. Vol. X: The Augustan Empire, 43 B. C. -A. D. 69]. Moscow, Ladomir: 373-393 (in Russian).

8. Adams J.P. 1985. Logistics of the Roman imperial army. Major campaigns on the eastern front in the first three centuries A. D. Ann Arbor, University Microfilms International, 298.

9. Alföldy G. 1987. Römische Heeresgeschichte. Amsterdam, Verlag J.C. Gieben, 575.

10. Berard F. 1989. La cohorte I a Cilicum, la classis Flavia Moesica et les vexillations de l'armée de Mésie inférieure: À propos d'une inscription de Montana. Zeitschrift für Papyrologie und Epigraphik, Bd. 79: 129-138.

11. Birley E. 1953. The equestrian officers in the Roman army. In: Birley E. Roman Britain and the Roman Army. Kendal, Titus Wilson \& son LTD, 1953: 133-153.

12. Bounegru O., Zahariade M. 1996. Les forces navales du Danube et de la Mer Noire aux Ier VIe siècles. Oxford, Oxbow Books, 1996, XII, 124.

13. Bowie E. 2014. Becoming wolf, staying sheep. In: Madsen J.M., Rees R. (eds.). Roman Rule in Greek and Latin Writing: Double Vision. Leiden, Brill, 39-78.

14. Brunt P.A. 1983. Princeps and Equites. The Journal of Roman Studies, vol. 73: 42-75.

15. Bruun C. 2015. Roman Government and Administration. In: Bruun C., Edmondson J. (eds.), The Oxford Handbook of Roman Epigraphy. Oxford, Oxford University Press: 274-298.

16. Campbell B. 1988. Rewiew: Reddé M. Mare Nostrum: Les Infrastructures, le Dispositif et l'Histoire de la Marine Militaire sous l'Empire Romain. The Journal of Roman Studies, vol. 78: 239.

17. Davenport C. 2019. A History of the Roman Equestrian Order. Cambridge, Cambridge University Press, xxv, 717. Rome, 923.

18. Demougin S. 1988. L'ordre équestre sous les Julio-Claudiens. Rome, École Francaise de

19. Devijver H. 1998. Commanders and officers of legio IIII Scythica. In.: Kennedy D.L. (ed.), The twin towns of Zeugma on the Euphrates: rescue work and historical studies. Portsmouth, RI: 205-232.

20. Eck W., Lieb H. 1993. Ein Diplom für die classis Ravennas vom 22. November 206. Zeitschrift für Papyrologie und Epigraphik, Bd. 96: 75-88.

21. Forni G. 1986. I diploma military dei classiari delle flotte pretorie (inclusi quelli dei classiari-legionari). In: Eck W., Wolff H. (Hrsg.), Heer und Integrationspolitik die römischen Militärdiplome als historische Quelle. Köln., Böhlau: 193-321.

22. French D.H. 1984. Classis Pontica. Epigraphica Anatolica, Bd. 4: 53-60.

23. Hassal M. 2007. The Army. In: The Cambridge Ancient History. Vol. 11. The High Empire, A. D. 70-192. Cambridge, Cambridge University Press: 320-343.

24. Holder P.A. 1982.The Roman Army in Britain. New York, St. Martin's Press, 173.

25. Isaac B. 1990. The limits of empire. The Roman Army in the East. Oxford, Clarendon Press, XIV, 510.

26. Keppie L. 1984. The making of the Roman army from Republic to Empire. London, B.T. Batsford Ltd, XI, 255.

27. Kissel Th. 1995. Untersuchungen zur Logistik des römischen Heeres in den Provinzen des griechischen Ostens (27 v. Chr. - 235 n. Chr.). St. Katharinen, Scripta-Mercaturae Verl, XI, 405.

28. Konen H.C. 2001. Classis Germanica die römische Rheinflotte im 1-3 Jahrhundert n. Chr. St. Katharinen, Scripta Mercaturae Verlag, 578. 
29. Kunić A.D. 1996. Classis Praetoria Ravennatium with special reflection on sailors that on sailors that origin from Dalmatia and Pannonia. Živa antika, sv. 46: 95-110.

30. Maurizi L. 2013. Il cursus honorum senatorio da Augusto a Traiano: sviluppi formali e stilistic nell'epigrafia latina e greca. Helsinki, Societas Scientiarum Fennica, XII, 324.

31. Maxfield V.A. 1990. Mainland Eurupe. In: Wacher J. (ed.), The Roman World. Vol. 1: 139-197.

32. Pflaum H.-G. 1950. Les procurateurs équestres sous le Haut-empire Romain. Paris, Adrien Maisonneuve, 357.

33. PIR2 - Groag E., Stein A. (iter. et edid.) 1936. Prosopographia Imperii Romani. Saec. I. II. III. Pars II. Sec. ed. Berolini et Lipsiae, XXII, 399.

34. Rankov B. 2008. Military forces. In.: Sabin P., van Vees H., Whitby M. (eds.) The Cambridge History of Greek and Roman Warfare. Vol. II: Rome from the Late Republic to the Late Empire. Cambridge, Cambridge University Press: 30-75.

35. Reddé M. 1986. Mare Nostrum: les infrastructures, le dispositif et l'histoire de la marine militaire sous l'empire romain (Bibliothéque des Écoles françaises d'Athènes et de Rome CCLX). Rome, École Française de Rome, ix, 737.

36. Rossi L. 1971. Trajan's column and the Dacian Wars. Ithaca, N.Y., Cornell University Press, 240.

37. Saddington D. 1990. The origin and nature of the German and British Fleets. Britannia, vol. 21: $223-232$.

38. Saddington D. 1991. The origin and Character of the provincial fleets of the Early Roman Empire. In: Maxfield V.A., Dobson M.J. (eds.), Roman frontier studies 1989. Proceedings of the XVth International Congress of Roman Frontier Studies. Exeter, University of Exeter Press: 397-399.

39. Sarnowski T. 1987. Zur Geschichte der Moesischen Provinzialflotte im 1 Jr. n. Chr. Ratiariensia, № 3/4: 261-265.

40. Soproni S. 1990. Vexillationes Classis Flaviae Pannonicae. In.: Vetters H., Kandler M. (Hrsg.), Akten des 14 Internationalen Limeskongresses 1986 in Carnuntum, Wien, Verlag der Osterreichischen Akademie der Wissenschaften: 731-736.

41. Southern P. 2007. The Roman Army. A Social and Instutional History. Oxford, Oxford University Press, XI, 383 p.

42. Strobel K. 1989. Die Donaukriege Domitians. Bonn, Habelt, 151.

43. Wagner G. 1995. Deux inscriptions grecques d'Égypte. Zeitschrift für Papyrologie und Epigraphik, Bd. 106: 126-130.

44. Webster G. 1998. The Roman Imperial Army of the of the First and Second Centuries A. D. (3d Edition). Norman, University of Oklahoma Press, XXIII, 349.

45. Wilkes J.J. 1983. Romans, Dacians and Sarmatians in the first and early second centuries. In.: Hartley B., Wacher J. (eds.), Rome and her Northern Provinces. Papers Presented to Sheppard Frere in Honour of his Retirement from the Chair of the Archaeology of the Roman Empire, University of Oxford. Gloucester, Alan Sutton: 255-289.

46. Żyromski M. 2001. Praefectus classis. The commanders of the Roman imperial navy during the Principate. Poznań, Wyd. Instytutu Nauk Politycznych i Dziennikarstwa Uniwersytetu im. A. Mickiewicza w Poznaniu, 2001, 157.

Конфликт интересов: о потенциальном конфликте интересов не сообщалось. Conflict of interest: no potential conflict of interest related to this article was reported.

\section{ИНФОРМАЦИЯ ОБ АВТОРЕ}

Телепень Сергей Валерьевич, кандидат исторических наук, доцент кафедры истории и обществоведческих дисциплин Мозырского государственного педагогического университета им. И.П. Шамякина, г. Мозырь, Белоруссия

\section{INFORMATION ABOUT THE AUTHOR}

Sergey V. Telepen, doctor of historical Sciences, associate Professor of the Department of History and Social Sciences, Mozyr State Pedagogical University named after I.P. Shamyakin, Mozyr, Byelorussia 